\title{
SEMIOTICS OF COLOR RED IN THE GIVER MOVIE
}

\author{
Emy Sudarwati' \& Nur Amalina Zatalini ${ }^{2}$ \\ ${ }^{1,2}$ Faculty of Cultural studies, Brawijaya University \\ Corresponding Author: Author's Name, Emy Sudarwati E-mail: \\ emysudarwati83@gmail.com
}

\begin{tabular}{l} 
ARTICLE INFO \\
\hline Received: 2019-11-27 \\
Accepted: 2019-11-27 \\
Published: October 2019 \\
Volume: 3 \\
Issue: 2 \\
DOI: \\
https://doi.org/10.33019/lire.v3i2.14 \\
\hline KEYWORDS \\
\hline
\end{tabular}

Semiotics, color, sign, movie

\section{ABSTRACT}

Color is a visual tool usually used in a movie which functions not only to make the movie looks good, but it is also to serve the story and build a character. Color brings a meaning behind its presences giving a sign that it can be interpreted accordingly. Chandler (2002) stated that sign is a meaningful unit which is interpreted as 'standing for' something other than itself. This current study analyzes the color red in The Giver movie as a sign based on semiotics approach. This study is a qualitative descriptive study. Document or content analysis is applied to analyze the captured scenes of The Giver movie which contains the color red. The study found out that the color red has several meanings behind its presences. The color is reflected in some properties. I found several things painted in color red around Jonas. The things are Viona's hair, apples, books, and clothes. Even though the things have the same color red, each of them has different meaning beyond. The color red itself and the things that possess it have related meanings to complete each other. Also, the meaning of color red is closely related to Jonas' character as the main character.

\section{INTRODUCTION}

Semiotics is a study about sign. Sign refers to anything which stands for something else. Umberto Eco stated that semiotics is concerned with everything that can be taken as a sign (1976, cited in Chandler 2002, p. 2). Chandler (2002, p.2) added, "Semiotics involves the study not only of what we refer to as 'signs' in everyday speech, but of anything which 'stands for' something else". From the explanation above, form of sign can be words, images, gestures, sounds, colors, and other objects. As a visual tools and storytelling, the color not only use to make the movie look good, but also to serve the story and built a 
character. The color brings a meaning behind its presences. Colors can be used to give a better understanding to the audiences. It has a power to influence how the audiences perceive the film and the characters. Based on the Studio Binder (2016), color can affect us emotionally, psychologically and even physically, often without us becoming aware. Color in film can build harmony or tension within a scene or bring attention to a key theme.

This study was conducted to analyze the color portrayed in the movie as the focus of the study entitled Semiotics of Color Red in The Giver Movie. The movie is selected because the way movie scene presented is different. Instead of using colorful scene, The Giver movie is presented in black and white. Around 2014, there are several movies also serve the same theme about a society as The Giver movie. However, all of them is presented in such colorful movie scene. The writers use the Piercean Model to analyze how color red is interpreted as a sign in The Giver movie. Then, the researchers analyzed the meaning behind the sign through the denotative and connotative meaning.

\section{LITERATURE REVIEW}

Red hair color is valued and respected in Europe. It has always had significant standing in society. Girls with red hair show their individuality. It gives meaning that they celebrate the difference and recognize otherness not as something to be scared of, but as enriching a valuable (Harvey,2015). That meaning is reflected by the character of Viona. She can accept Jonas's idea although she knows that it is against the rule. At the end, she helps Jonas to escape because she believes what Jonas does is for the good. Viona shows their individual decision and is not afraid to be punished because she can feel the emotion.

Basically, apple has two colors namely green and red. However, red apple is the one that often appears in the movie. Apples appear in many religions, often as a dangerous or forbidden fruit. In the Christian tradition,apple becomes a symbol for knowledge, immortality, temptation and sin (Claire, 2015).

\section{METHODOLOGY}

This study used qualitative approach since the study discusses the semiotics of color red. The type of this study is document or content analysis because according to Ary, Jacobs, Razavieh, \& Sorensen. (2010, p.457), "Content or document analysis is a research method applied to written or visual materials for the purpose of identifying specified characteristics of the material."

Data Sources of this study were taken from The Giver movie directed by Philip Noyce (2014). The data is film scenes that contains the sign of color red since the writers focused this study on the color red.

The writers conducted this study through some steps. The first was watching the movie several times in order to understand the component well. While watching the movie, the writers also took some notes related to the scenes which contain the color red then capturing the scenes which contain color red and related object as data sources after watching the movie. 
After collecting the data, the writers took some steps to analyze the color red as a sign. First, the writers analyzed the data using Peircean Model in order to answer the first problem of the study, to find out how color red found in The Giver movie is interpreted as a sign. Second, the writers analyzed the meaning behind color red based on its denotative and connotative meaning. The last step was drawing conclusions based on the analysis and interpretation that were done.

\section{RESULTS AND DISCUSSION}

There are several scenes that contain the color red. Most of them appear after Jonas doing his traineeship with the previous giver. The giver shares memories about snow, slide, emotion, love, pain, color, race and religion to Jonas. Red is the first color Jonas sees. I found that the appearances of color red is related to the Jonas's action. So, I discussed more on Viona's red hair, red apples, red books, and dominant color red in memories of the past that Jonas sees.

\section{The Main Character, Jonas, Seesthe Color Red in Viona's Hair}

Jonas sees the quality of the Viona's hair which is the color red when Jonas, Viona and Asher are doing their volunteer activity in the nurturing center. At that time, one of the babies in nurturing center is crying. Jonas's father, a nurturer who works in there, says that they can touch the baby to comfort him. Jonas holds the baby's hand, but the baby keeps crying. Then, Viona successfully comforts the baby by patting the baby's head.This scene is still presented in black and white in order to show the sameness in the community.

The color changes appearwhen Jonas talks with his father, then he is distracted by Viona. He notices there is something different in Viona's hair. In the scene, it shows by the changes of Viona's hair color into red. Meanwhile, the other objects except the Viona's hair, are still in black and white. Viona, who feels noticed by Jonas, looks him back. Then, the color of Viona's hair changes back gradually.

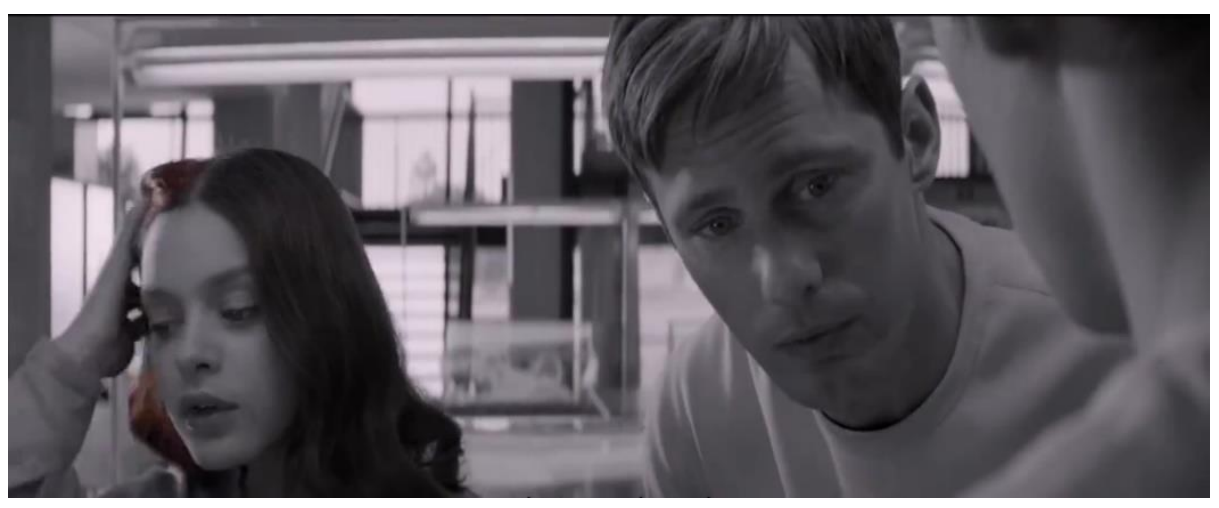

Figure 3.1.a Viona's hair color change into red.

\section{Analysis of the Sign}

a. Symbolic Mode

1. The color red of Viona's hair 
2. Black and white color of the scene

b. Iconic Mode

1. Icon of a girl with wavy hair

2. Icon of a man with straight hair

3. Icon of a person from behind

4. Icon of a storage

c. Indexical Mode

1. The man expression indicates they have a serious conversation

2. Viona's calm expression indicates she doesn't know about the color change of her hair into red

\section{Analysis of the Meaning}

The color changes of Viona's hair into red symbolize Jonas interest toward Viona since he sees it differently. The color red that he sees in Viona's hair is beyond what he sees in another usual thing. The color red itself brings meaning of desire, romance and love. In this case, Jonas seems having some desire or deep feeling toward Viona.He always thinks about Viona. Even, he had a dream kissing Viona.

Meanwhile, the color red brings the symbolism of deep emotion, love and sexual interest toward opposite gender, Viona's red hair is an icon of a young beautiful girl.

The denotation meaning of red hair is any of the fine threadlike strands growing from the skin of humans, mammals, and some other animals, and hairs collectively, especially those growing on a person's head which is having a reddish-blonde or orangebrown color.

Meanwhile red is a color at the end of the spectrum next to orange and opposite violet, as of blood or rubies, (of hair or fur) of a reddish-brown color. The color red is a stand out color and easy noticed. The color red is often used to color something in order to differentiate it with something else. In film scene, the color red is often used to refocus audience's attention to a specific person, place, or things. The color red is also used to build the character and detail. It gives an effect to the audience's perception. The color red brings a meaning that Viona is a special person for Jonas.

Then, red hair color is valued and respected in Europe. It has always had significant standing in society. Girls with red hair show their individuality. It gives meaning that they celebrate the difference and recognize otherness not as something to be scared of, but as enriching a valuable (Harvey,2015). That meaning is reflected by the character of Viona. She can accept Jonas's idea although she knows that it is against the rule. At the end, she helps Jonas to escape because she believes what Jonas does is for the good. Viona shows their individual decision and is not afraid to be punished because she can feel the emotion.

\section{Color Red on An Apple}

There are several scenes showed the red apple. The apples are served in every dwelling or family unit. The Apples are the first red thins that Jonas sees. Also, Jonas always use the apple to manipulate his morning injection. 
LIRE JOURNAL (JOURNAL OF LINGUISTICS AND LITERATURE)

P-ISSN: $\underline{2598-1803}$

E-ISSN: 2581-2130

Volume 3 Number 2 October 2019

\section{Analysis of the Sign}

After getting the memories of color from the giver, the first thing that Jonas sees is red apples. In the dialog, he mentions, "It is red, just like her hair".Her hair means Viona's hair, the color changes that Jonas sees before he gets the memories about color.

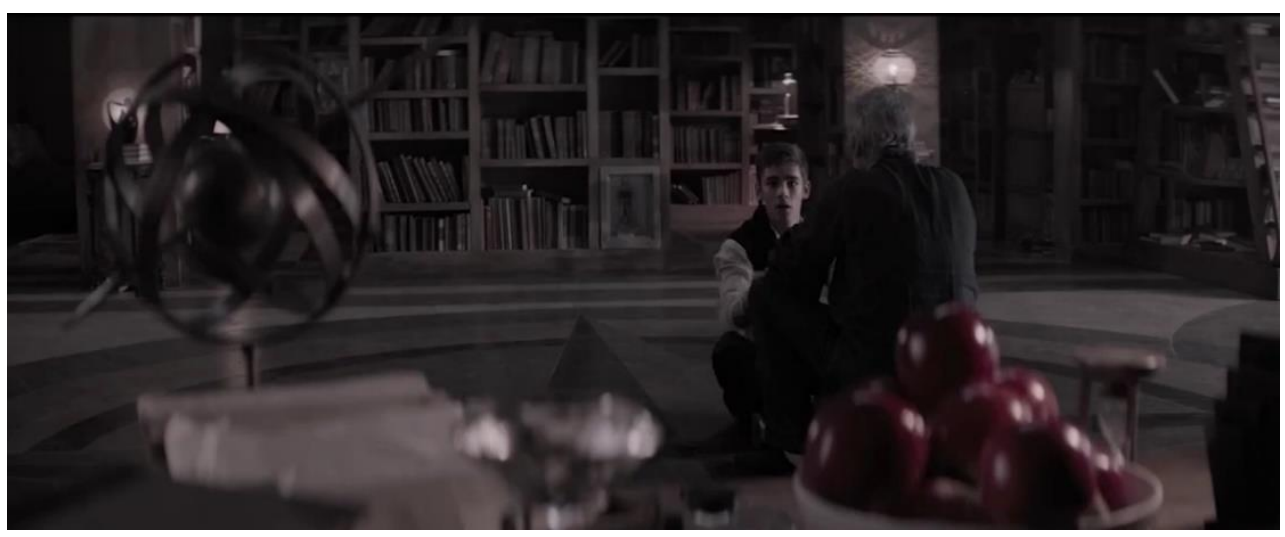

Figure 3.2.b Jonas sees the red apple

a. Symbolic Mode

1. The color red of apples

b. Iconic Mode

1. Icon of red apples

2. Icon of a globe

3. Icon of an old man in black cothes from behind

4. Icon of a boy

5. Icon of books in bookshelf

c. Indexical Mode

1. The boy's shocking expression indicates he is surprised by the red apple

2. The light lamp indicating they are in dark place.

The red apples appear in several scene of The Giver movie. The other one is a scene when Jonas uses the apple to manipulate morning injection. The injection itself is used to prevent emotion. 


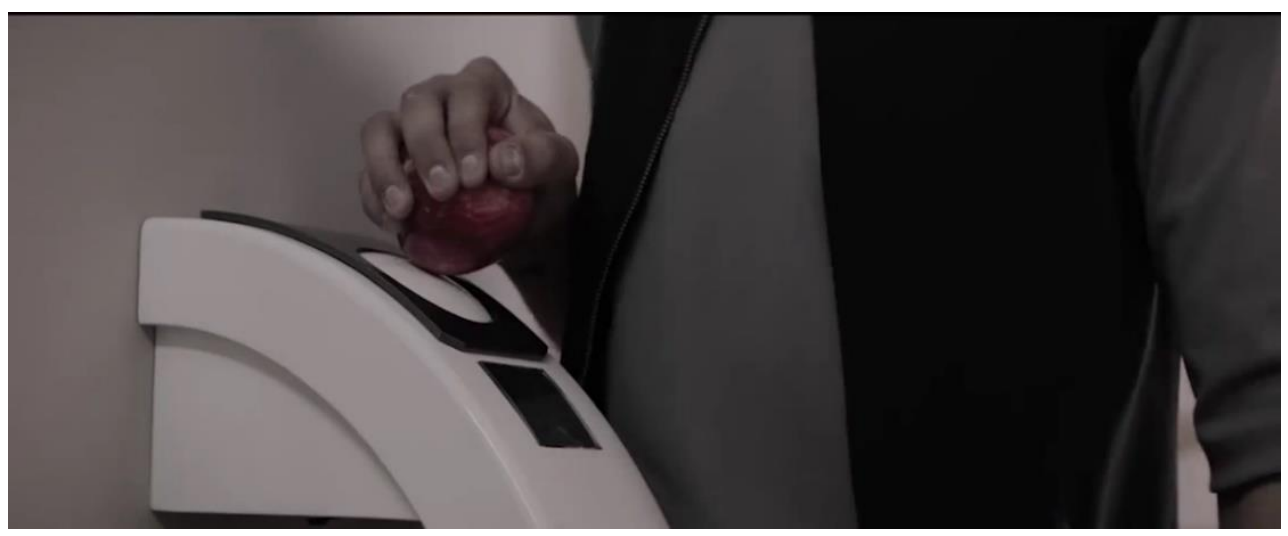

Figure 3.2.c Jonas uses the apples to skip the morning injection
a. Symbolic Mode
1. The color red of apples
b. Iconic Mode
1. Icon of a red apple
2. Icon of a hand
3. Icon of a boy's body
4. Icon of an injector

c. Indexical Mode

1. The position of body is cover up the action from behind indicates he does it secretly.

\section{Analysis of the Meaning}

Color red of the apple symbolizesaction, confidence, and courage. It shows Jonas's courage in against the rule (skipping the morning injection). Also, the red apple is the first red thing Jonas recognizes. It indicates his courage in the next action as he responds toward the memories he gets. The pressure of the pain leads him to take a series of action and challenge his own self.

Jonas makes a deal with Viona. Viona willing to skip her morning injection if Jonas promises he won't quit his position. Even though, both of them know well if what they do is against the rule, they try to face the danger and the risk. Viona really skips her morning injection. It makes Viona feel a little bit of emotion that has been erased. The denotation meaning of red apple is the rounded fruit of a tree of the rose family, with red skin and crisp flesh.

Basically, apple has two colors namely green and red. However, red apple is the one that often appears in the movie. Apples appear in many religions, often as a dangerous or forbidden fruit. In the Christian tradition,apple becomes a symbol for knowledge, immortality, temptation and sin (Claire, 2015). Related to the meanings of color red and the apple above, the color red on the apple in The Giver movie implies the meaning of the danger that Jonas will face as the next giver. He has to overcome all of the pain of the past memories. Since, he is the only one person in the community who has knowledge about the past. That position is such an honor, but also brings him self to many risks and 
danger.He has to be brave and strong enough. In the end of the movie, he has to make a choice to leave the community in order to save Gabriel.His confidence that his belief is right leads him to do things against the rule. His courage makes him take a long way to pass the boundary

\section{The Color Red of the Book}

The red books appear in the scene when Jonas receives the memories of coloring in the giver house.

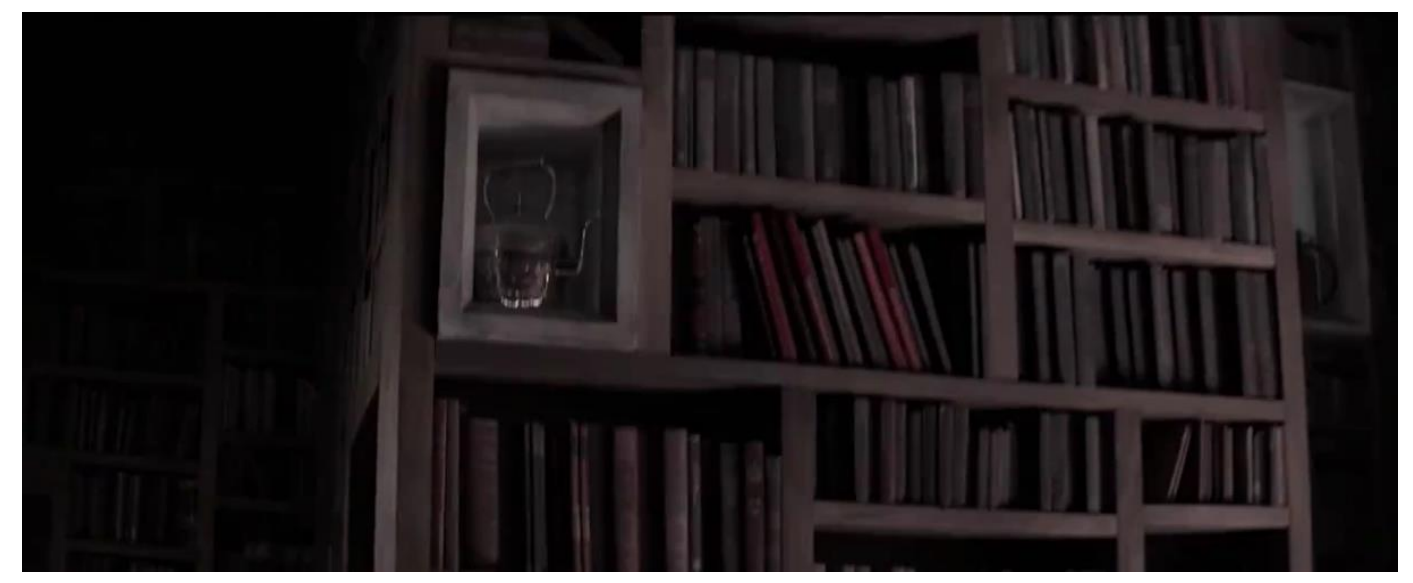

Figure

3.3.d The red books in the giver's house

\section{Analysis of the sign}

a. Symbolic Mode

1. The color red of books

b. Iconic Mode

1. Icon of books

2. Icon of a wooden bookshelf

3. Icon of a kettle

c. Indexical Mode

1. Many books in the house indicates the person likes reading

\section{Analysis of the meaning}

The color red is determined color. It symbolizes the differences with other. Asthe next giver, Jonas is different from the rest of community members. He has the quality to see beyond. Also, he has more knowledge than others. As the chief elder says, Jonas possesses all four attributes: intelligence, integrity, courage, and one she can name, but she cannot describe, the capacity to see beyond (The Giver, 2014). The denotation meaning of book is a written or printed work consisting of pages glued or sewn together along one side and bound in covers. Red book means the book has color red.

There are so many books shown in the giver's dwelling. The book implies knowledge. Since the giver has memories of the past, his knowledge is very important for the community. The giver has to give a wise solution based on the memories he has if the elders of the community face a problem. Also, the red book is the things that Jonas sees 
beside the red apple. In the future, Jonas has to be wise in using his knowledge about the past. He is the one who can change the community life.

\subsection{Jonas's Past Memories and Vision}

The giver is the only one who has the memories of the past. Then, Jonas is selected to be the next giver. It makes him the receiver of the memories. The previous the giver passes the memories to Jonas and gives him some lessons. He gives memories about love, pain, color, race, also religion. In the memories, color red looks dominant. The color appears almost in all of Jonas's memories and vision.

\section{Analysis of the sign}

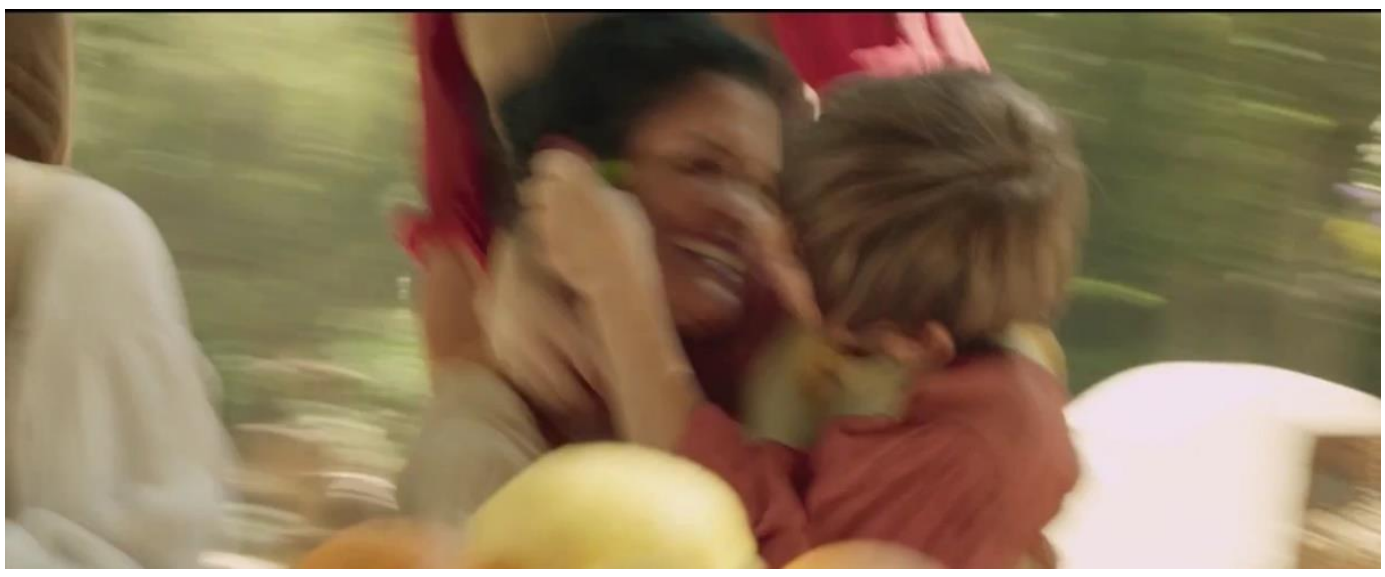

Figure 3.4.eCaptured moment of wedding ceremony in Jonas's memories related to emotion

a. Symbolic Mode

1. The color red of the clothes

b. Iconic Mode

1. Icon of a young boy

2. Icon of a women or mother

c. Indexical Mode

1. The mother's laugh indicates she is having fun with the boy or his son

2. Blur scene indicates the moment is taken in short 
LIRE JOURNAL (JOURNAL OF LINGUISTICS AND LITERATURE)

P-ISSN: 2598-1803

E-ISSN: 2581-2130

Volume 3 Number 2 October 2019

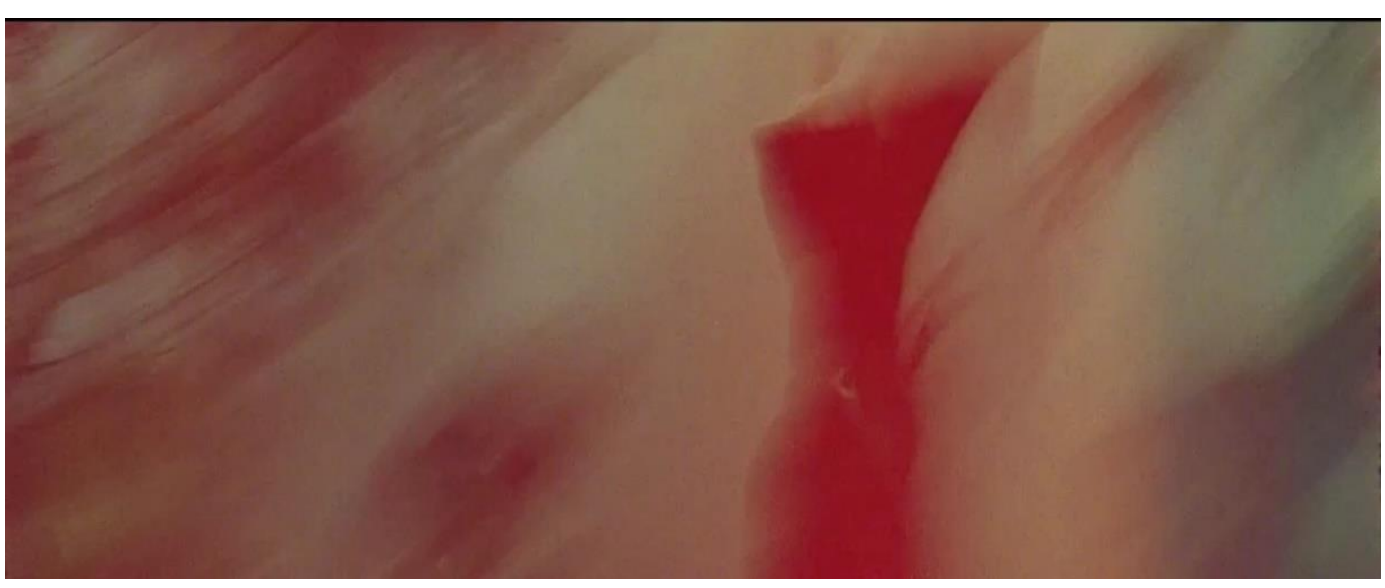

Figure 3.4.f Memories of the war

a. Symbolic Mode

1. The red flash

b. Iconic Mode

1. Icon of something in red

c. Indexical Mode

1. The blur scene indicates the war occurs very quick

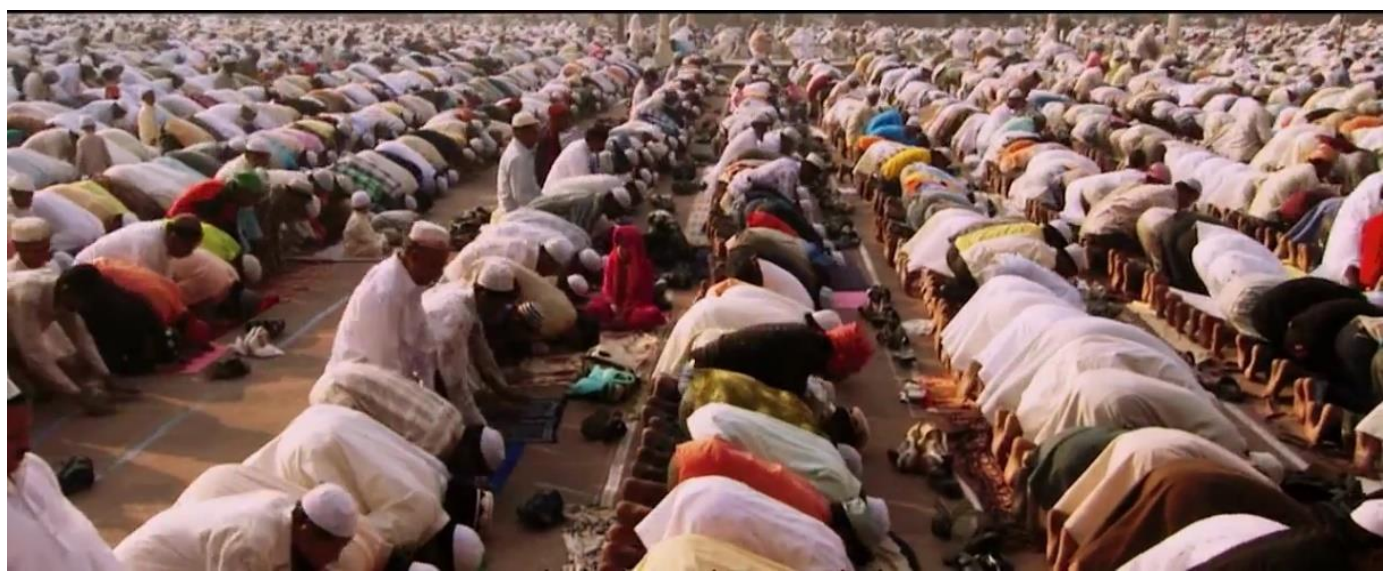

Figure 3.4.h Memories of religion

a. Symbolic Mode

1. The "Sujud" move

b. Iconic Mode

1. Icon of Moslem people praying

2. Icon of a young girl sits in red

3. Icon of a young boy sits

c. Indexical Mode

1. The outfit and action indicate they are Moslem 
LIRE JOURNAL (JOURNAL OF LINGUISTICS AND LITERATURE)

P-ISSN: 2598-1803

E-ISSN: 2581-2130

Volume 3 Number 2 October 2019

2. The move (Sujud) indicates they are doing Sholat together

3. A lot of people indicate they are in wide place such as field

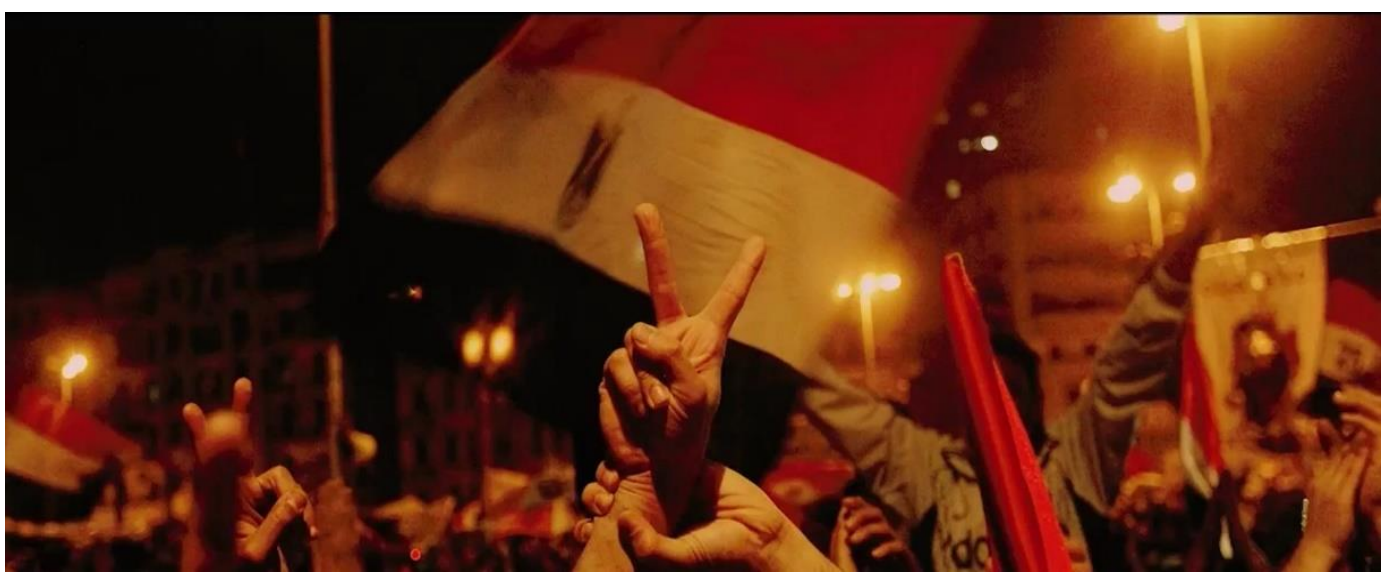

Figure 3.4.g Captured memories from the giver to Jonas before he is leaving the community

a. Symbolic Mode

1. The "peace" signs

2. The flag

b. Iconic Mode

1. Icon of a hand doing "peace" sign

2. Icon of a flag

3. Icon of a person

4. Icon of building

c. Indexical Mode

1. The condition showed indicates they are doing an oration

2. The dark sky and the light lamp indicates it takes places in the night

\section{Analysis of meaning}

The color red symbolizes love, desire, passion, action and deep emotion. The color also brings meaning of differences and danger. The symbolism of love can be seen in the memories of wedding ceremony. Most of people use red clothes in the celebration. Shown in figure 3.4.f, it shows the relation of a mother and her child which are smiling and happy. Their togetherness reflects their love to each other. They share an emotion and enjoy it.

The giver also gives memories about race and religion. In figure 3.4.h, it shows the Moslem doing Sholat together. There are two young children sit between the people praying. The white boy in white outfit and the girl in red. If we see the picture, our attention will be distracted to the girl in red despite the boy behind. The red outfit and the difference action make her easy to get noticed. 
The color red is used to indicate the danger is shown in figure 3.4.g, memories of the war. The giver passesa memory of war to Jonas in order for him to understand the real pain. However, at the first the giver didn't plan to pass it at that time. He shares the memories accidentally. Then, Jonas sees his friends were killed in the field. The memories roll in red flashlight with the sounds of gun.

The color red reflects the action people take. In figure 3.4.i, it shows a hand hold the other one hand which is doing peace signs. They seem in an oration we're taken until the dark. Peace signs often use to symbolize cessation of war. The color red reflects behind the action we also have to brave enough to face the risk behind. We have to take wise decision in order to create a peaceful life.

\section{Discussion}

Related to the finding of the study, the color red has several meanings behind its presences. The color red can analyze as a sign. In this case, the writers used the Peircean Model (1982) in order to analyze how the color red is interpretedin The Giver movie. Used this Peircean Model, the writer found out that the color red can be categorized as a symbol. Then, the writer analyzes the denotative and connotative meaning behind the color red.

Understanding the connotative meaning helps us to know more about the meaning behind the color. The meaning of color can be different based on the context. In The Giver movie, the color appears after Jonas gets the memories about color. The color red is the first color he recognizes. The color red appears in the scenes when Jonas is involved in there. The appearances of color red are triggered by Jonas's actions. The writer found out that the color red appears when Jonas meets Viona, the girl that Jonas likes. Second, the color red appears when Jonas manipulates his morning injection. Also, color red appears in the scene when Jonas leaves the community with Gabriel to pass the boundary. It shows that the appearance of color red related to the Jonas's love and action in violating the rules. Also, the color red appears in the past memories, like the mother and her child, the praying, the war, and the oration is still related to Jonas's action. The appearances of the color red in the memories of a mother and her child is related to Jonas's knowledge about love. Besides the love, people also suffered from pain as the consequences of their action. As the next giver, Jonas has knowledge that makes him different from the rest of the community member. It makes him do some action which is considering as against the rule even he had a good reason. The rest of the community member cannot understand it because they cannot feel the emotion erased. The color red appears in the memories of the past which is influence Jonas's action in violating the rule.

The color red is not stand out by itself. The color is reflected in some properties. The writer found several things painted in color red around Jonas. The things are Viona's hair, apples, books, and clothes.

The writer analyzes each of the sign reflected in those things mentioned above. Even though the things have the same color red, each of them has different meaning beyond. The color red itself and the things that possess it have related meanings to complete each other. 
Viona's red hair symbolizes the love and desire. Even, Jonas can see the color before he gets the memories of color from the past. He looks like having an interest toward Viona. The color changes Jonas sees also indicate that Jonas is different from the rest of community members. He possesses the ability to see beyond. Then, his courage and action are symbolized by the red apples. In order to save Gabriel, Jonas takes the consequences and does his action. He is not affraid to do things against the rules because he believes that what he does is right. Moreover, he has been skipping the morning injection in one month using the red apple. This apple is also used by Viona to skip the morning injection as Jonas asks. In other word, the red apples are also related to Jonas's relation with Viona. Apple is often called as forbidden fruit (Claire,2015). In this movie, Jonas also uses it to do something forbidden. The another thing that writer found is red book. The book reflects the knowledge of the giver. His knowledge about the past is the one that makes him different from the other member of the community. This position is such an honor, but it has so many risks and dangers. The meaning of color red is also reflected in the memories from the past and Jonas's vision. The memories show a lesson about love, pain, color, race, and belief.

Furthermore, the meaning of color red is closely related to Jonas character. Beside to make the movie more interesting, the color is used to serve story and built a character. It gives a better understanding to the audiences in perceiving the meaning of the movie. Related to the theory of color in chapter II, the meaning of color red is suitable for Jonas's character in this movie. The color red portrays Jonas's love, desire and courage. Based on the previous studies, there is the similarity in the use of color red in Veronika's study. In Bram Stoker's Dracula movie, color red as the uncontrolled reflected sexuality or deep desire.

In The Giver movie, the community is set by the principle of "sameness". Therefore, they do not understand about differences. Every individual is treated the same. They do not have a freedom to make a choice in their life. They believe the freedom just make people choose wrong and make the world away from peace. That is why they erased all of memories from the past and created an ideal community as they believe. Those community principle is shown by black and white scene.

Since the writers set a limitation in analyzing the color red, this study only provides the meaning behind the color red that appears in this movie. Even though, there are some other colors shown in The Giver movie. The writer chose the color red only because the color is considered to have an important role in this movie in built the main character, Jonas. Hopefully, there will be similar research in the future that analyzes all of the colors involved in The Giver movie. So, the analyzes will be more complete and cover up the lack of this study.

\section{CONCLUSION}

The writers make some conclusion after finishing the study. The first, color can be analyzed as a sign because color have certain meaning behind its presence.Especially, color in a movie. Second, the use of color in a movie is related with the story and the 
character. Color is not only used to make movie interesting, but also to serve several meanings in order to build a character.

In The Giver movie, the color red is used to build a character of Jonas, the main character. The color red possessess in some properties like Viona's hair, apples, books and clothes. Then, the writer found out that even though having the same color, the meaning of color can be different based on the context. The color red of Viona's hair indicates Jonas's interest toward Viona. It implies love and desire. In the apple, color red symbolizes Jonas's action, confidence and action. Then, the meaning of color red on the books is related to his knowledge and his passion to see beyond that makes him different from the rest of the communitymembers. The third, analyzing the sign using connotative meaning is suitable in order to understand the meaning behind well.At least, knowing the meaning of the color is really helpful. We can apply it not only in a movie, but also in our everyday life.

\section{ABOUT THE AUTHOR(S)}

The author is the lecturers from University of Brawijaya, Malang, East Java.

\section{References}

Ary, D. et al. (1972). Introduction to Research in Education. New York: Holt, Rinehart andWinston, Inc.

Chandler, D. (2002). The Basic semiotics. London and New York: Routledge.

Claire. (2015). Symbols and Their Meaning: The Apple. Retrieved May 21, 2018, from www.jweel.com/en/blog/p/2015/symbols-and-their-meaning-the-apple/

StudioBinder. (2016). How to Use Color in Film. StudioBinder Inc.

The Giver. (2014). Retrieved from https://m.imdb.com/title/tt0435651 